\title{
Dietary Reference Intakes for the Cuban Population, 2008
}

\author{
Manuel Hernández-Triana, MD, PhD, Carmen Porrata, MD, PhD, Santa Jiménez, MD, PhD, Armando Rodríguez, PhD, Olimpia \\ Carrillo, PhD, Álvaro García, PhD, Lourdes Valdés, PhD, Mercedes Esquivel, MD, PhD
}

Recommended dietary reference intakes (DRI) for energy and nutrients for the Cuban population were first established by the Nutrition and Food Hygiene Institute (INHA, its Spanish acronym) in 1996.[1] International organizations and Cuban public health research subsequently generated a considerable volume of new information on food-based energy and nutrient requirements,[2-4] resulting in the need for a revision. Updated DRIs were therefore compiled by a multidisciplinary group of specialists and published in 2008 by INHA and the Cuban Ministry of Public Health.[5,6]

The current recommendations establish adequate intakes for energy, protein, essential amino acids, fats, carbohydrates, dietary fiber, 14 vitamins, and 15 minerals or trace elements, as well as tolerable upper intake levels for some nutrients. To facilitate dietary planning, population-averaged dietary reference intakes are provided for the total Cuban population $(2300 \mathrm{kcal}$, $69 \mathrm{~g}$ protein, $53 \mathrm{~g}$ fat, and $387 \mathrm{~g}$ carbohydrates) and by age group. Important changes include the use of body weight corresponding to a Body Mass Index (BMI) of 21 to establish the recommended energy intake for adults, and setting the recommended fat intake as $20 \%$ of total energy-quantities aimed at preventing overweight and the noncommunicable chronic diseases most prevalent in Cuba.

The dietary reference intake is the amount of a particular nutrient required to sustain normal metabolic, physical and psychic functioning; promote health and quality of life; prevent deficiency diseases and excess intake; and guarantee certain reserves for emergency situations. Recommended amounts are calculated to meet these needs in the majority of the population, taking into account diverse environmental conditions and life situations.

Dietary recommendations are an important regulatory and educational tool for all sectors concerned with food and nutrition. They are fundamental to nutritional planning and to setting national policies aimed at safeguarding a healthy diet for the population. DRIs serve as targets in calculating availability of foodstuffsdomestically produced and imported-as well as in setting affordable pricing policies. Food and pharmaceutical industries use DRIs as guidelines for producing fortified foods and nutritional supplements for population groups with particular needs. They are also used as reference values for assessing food consumption surveys (at individual and macroeconomic levels) and for creating dietary guidelines.

The following is a summary version of the 2008 dietary recommendations for the Cuban population.[5]

\section{Energy and Macronutrients (Tables 1 and 2) \\ Energy}

- Infants and children aged <3 years Recommended amounts for this age group were based on 1985 Joint FAO/ WHO Expert Committee criteria,[3] but 2006 WHO weightfor-height standards[7] were used as reference values for children aged $<1$ year, while 2006 Havana Growth and Development Study values[8] were used for children aged 1-3 years.

- Children aged $\geq 3$ years and adolescents DRIs were based on the needs of this age group, classified as having an "active" physical activity level (PAL), [2-4,9,10] and on 2006 Havana Growth and Development Study weight-for-height reference values.[8]

- Adults DRls were based on 2004 Joint FAO/WHO Expert Committee criteria,[3] which used the 1985 Committee's methodology for this age group.[11] Results of INHA's most recent research on Cuban adults were also taken into account.[12-16] Adults were grouped by PAL (sedentary, low active, active, very active, exceptionally active), and DRI was established for each group.[17] Given the high prevalence of overweight and chronic diseases in Cuban adults,[18] weight values corresponding to a Body Mass Index of 21 were used, as proposed by the World Health Organization, to prevent noncommunicable chronic diseases.[19]

- Pregnant women Additional energy recommendations for this group were established considering weight gains observed in a 2005-2007 study of pregnant women in Cuba. [20] Adding $85 \mathrm{kcal}, 285 \mathrm{kcal}$, and $475 \mathrm{kcal}$ in the first, second and third trimesters is recommended. For pregnant women who are malnourished and those with low weight for gestational age, an additional $675 \mathrm{kcal}$ is recommended.

- Lactating women Additional energy needs were established assuming that a well-nourished woman's breast milk contains $0.67 \mathrm{kcal} / \mathrm{g}$ energy. An additional $500 \mathrm{kcal}$ is recommended during the first 6 months of lactation and $400 \mathrm{kcal}$ thereafter.

\section{Proteins}

Recommendations were based on the 2007 Joint WHO/FAO/ UNU Expert Consultation on Protein and Amino Acid Requirements in Human Nutrition,[21] which propose that protein constitute $10 \%$ of total energy intake in children aged $<1$ year and $12 \%$ of total energy intake for all other ages. For children aged $<1$ year, $70 \%$ of total protein should be of animal origin; for all other ages, the recommendation is $50 \%$. The same FAO/WHO Requirements were also used to establish DRIs for Essential Amino Acids.

\section{Fats}

DRIs were established as a percentage of total energy intake: $40 \%$ for infants aged $<6$ months; $35 \%$ for children aged 6 months to 2 years; $25 \%$ for children aged 2-6 years, pregnant and lactating women, and exceptionally active adults; $23 \%$ for children aged $7-13$ years, and $20 \%$ for all other ages. Minimum fat intake should cover at least $15 \%$ of total energy intake. Fatty acid composition in baby formula should match fatty acid amounts and proportions in breast milk. Total energy intake should not include more than $10 \%$ saturated fatty acid, $15 \%$ monounsaturated fatty acid or $7 \%$ polyunsaturated fatty acid. Desirable intake of linoleic acid should provide $5 \%$ of energy. The recommended ratio of omega- 6 to omega- 3 fatty acids is $5: 1$. Cholesterol consumption should be less than $300 \mathrm{mg},[4]$ and it is recommended that trans 
Table 1: Dietary Reference Intakes, Energy and Macronutrients, Cuban Females

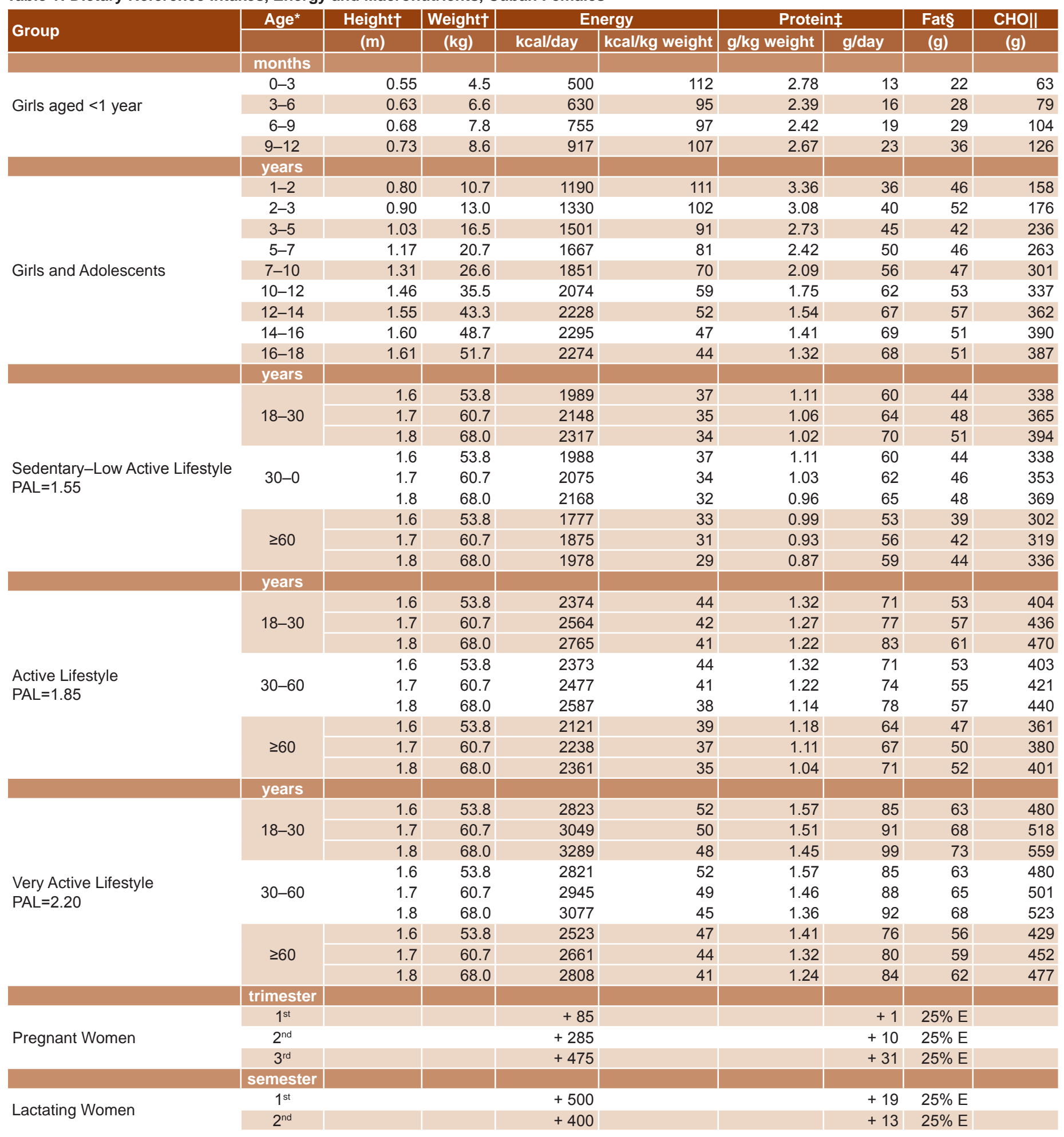

PAL: Physical Activity Level

E: Total energy intake

* Age intervals do not include upper limit.

† Height and Weight. Girls aged < 1 year: Median is the midpoint of the age interval, WHO, 2006.[7] Girls and adolescents: Median is the midpoint of the age interval, Metropolitan Havana, 2006.[8] Adults: Ideal weight for BMI=21.

$\ddagger$ Protein calculated as percentage of total daily energy intake. Aged $<1$ year: $10 \%$ (70\% animal protein); aged $\geq 1$ year: $12 \%(50 \%$ animal protein).

$\S$ Fat calculated as percentage of total daily energy intake ( $60 \%$ vegetable origin). Aged $<6$ months: $40 \%$; aged 6 months to 2 years: $35 \%$; aged 3-6 years and pregnant, lactating or exceptionally active women: $25 \%$; aged $7-13$ years, $23 \%$; aged $\geq 13$ years: $20 \%$.

$\| \mathrm{CHO}$ (Carbohydrates) calculated as difference in percentage of total daily energy intake after protein and fat values established. Complex $\mathrm{CHO}$ : $75 \%$. Dietary fiber, aged $19-50$ years: 25 g/day. Sugar: $\leq 10 \%$. 
Policy \& Practice

Table 2: Dietary Reference Intakes, Energy and Macronutrients, Cuban Males

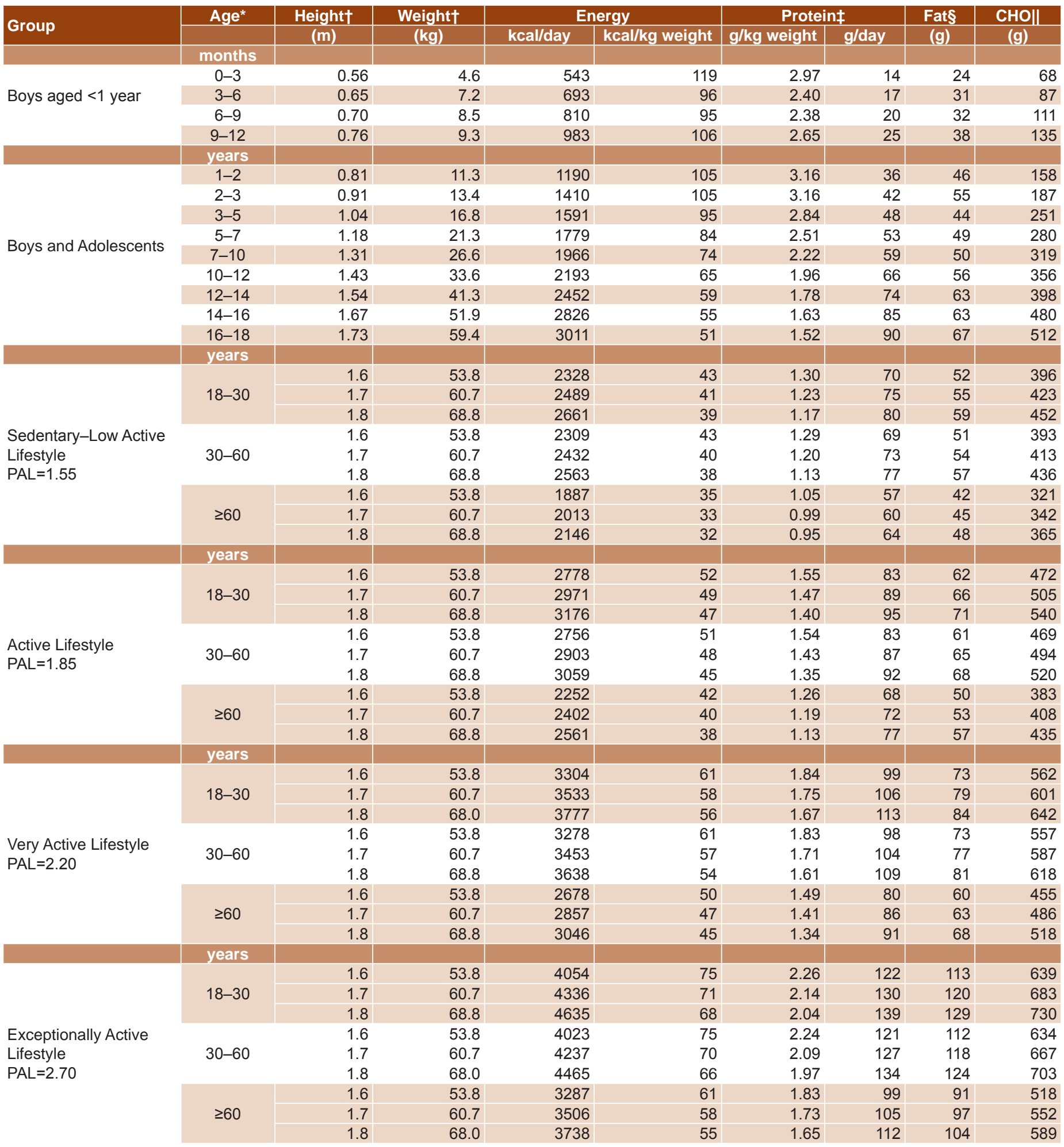

PAL: Physical Activity Level

*Age intervals do not include upper limit.

$\dagger$ Height and Weight. Boys aged <1 year: Median is the midpoint of the age interval, WHO data, 2006.[7] Boys and adolescents: Median is the midpoint of the age interval, Metropolitan Havana data, 2006.[8] Adults: Ideal weight for BMl=21.

$\ddagger$ Protein calculated as percentage of total daily energy intake. Aged $<1$ year: $10 \%(70 \%$ animal protein); aged $\geq 1$ year: $12 \%$ (50\% animal protein).

$\S$ Fat calculated as percentage of total daily energy intake (60\% vegetable origin). Aged <6 months: $40 \%$; aged 6 months to 2 years: $35 \%$; aged 3-6 years and exceptionally active men: $25 \%$; aged $7-13$ years, $23 \%$; aged $\geq 13$ years: $20 \%$.

II CHO (Carbohydrates) calculated as difference in percentage of total daily energy intake after protein and fat values established. Complex $\mathrm{CHO}$ : $75 \%$. Dietary fiber, aged 19-50 years: 38 g/day. Sugar: $\leq 10 \%$. 
isomer fatty acid intake be limited to $1 \%$ total energy, equivalent to $2 \mathrm{~g} /$ day in a $2000 \mathrm{kcal}$ diet.[22]

\section{Carbohydrates}

DRIs have been established only recently. For the first time, a 130 $\mathrm{g}$ minimum carbohydrate intake was established for everyone except children aged $<1$ year, based on the brain's average glucose demand. DRIs for carbohydrates are calculated as the percentage remaining once protein and fat portions of total energy intake has been established. Complex carbohydrates should make up $75 \%$ of the recommended carbohydrate intake and simple carbohydrates the remaining $25 \%$. Sugar should not exceed $10 \%$ of total energy intake.

\section{Dietary Fiber}

For children aged $>2$ years, adequate intake values proposed by $\mathrm{CJ}$ Williams in 1995 were used,[23] calculated as age plus an additional $5 \mathrm{~g} /$ day ( $8 \mathrm{~g} /$ day for children aged 3 years up to $25 \mathrm{~g} /$ day at age 20 years). For adults aged $19-50$, adequate intake is $25 \mathrm{~g} /$ day for women and $38 \mathrm{~g} /$ day for men, and for those aged $>50$ years, 21 g/day for women and $30 \mathrm{~g} / \mathrm{day}$ for men.[4] The tolerable upper intake level is $55 \mathrm{~g} /$ day for adults and the sum of age plus $10 \mathrm{~g} /$ day for children.

\section{Vitamins}

DRIs for vitamins in Cuba were based on recommendations proposed by the 2001 FAO Expert Committee,[24] the Food and Nutrition Board of the US National Academy of Sciences,[4] and the most recent results of INHA research on the Cuban population's vitamin nutritional status.[25-37]

\section{Vitamin A}

DRIs were established as 375-400 $\mu \mathrm{g}$ Retinol Activity Equivalent (RAE) for children aged $<1$ year, 400-600 $\mu$ g RAE for children aged $\geq 1$ year and adolescents, $600 \mu \mathrm{g}$ RAE for men, $500 \mu \mathrm{g}$ RAE for women, $800 \mu \mathrm{g}$ RAE for pregnant women, and $850 \mu \mathrm{g}$ RAE for lactating women. The following new conversion factors for carotenoids in active Vitamin A were used:

$1 \mu \mathrm{g} \operatorname{RAE}=1 \mu \mathrm{g}$ all-trans retinol or $12 \mu \mathrm{g} \beta$-carotene or $24 \mu \mathrm{g}$ $\alpha$-carotene or $\beta$-criptoxantine

$1 \mathrm{IU}$ retinol $=0.3 \mu \mathrm{g}$ retinol or $3 \mathrm{IU} \beta$-carotene.

Tolerable upper intake levels for Vitamin A (retinol only) are 600$900 \mu \mathrm{g}$ for children aged $\leq 8$ years, $1700 \mu \mathrm{g}$ for those aged 9-13 years and $3000 \mu \mathrm{g}$ for adults. Tolerable upper intake levels for pregnant women were set by INHA in 1998.[38]

\section{Vitamin D}

Recommendations were set at $5 \mu \mathrm{g}$ colecalcipherol for children and adults aged $0-50$ years, $10 \mu \mathrm{g}$ for adults aged $50-65$ years, and $15 \mu \mathrm{g}$ for adults aged $>65$ years. Tolerable upper intake level is $25 \mu \mathrm{g}$ for infants and $50 \mu \mathrm{g}$ for children and adults.

\section{Vitamin E}

Given the varied activities of different Vitamin E compounds, Vitamin $E$ activity is expressed as $\alpha$-tocopherol ( $\alpha-E T)$ :

$1 \alpha$-ET $=1 \mathrm{mg}$ a-tocopherol or $2 \mathrm{mg} \beta$-tocopherol or $3 \mathrm{mg}$ a-tocotrienol or $10 \mathrm{mg}$ y-tocopherol.

DRI is 4-6 $\alpha$-ET for children aged $<1$ year, 6-7 $\alpha$-ET for children aged $1-9$ years, $11 \alpha-E T$ for those aged $10-13$ years, and 15
$\alpha-E T$ for adolescents and adults aged $\geq 14$ years. The tolerable upper intake level is $200-800$ a-ET for children and adolescents, and $1000 \alpha$-ET for adults.

\section{Vitamin K}

Research appears to indicate that $1 \mu \mathrm{g} / \mathrm{kg} /$ day intake is sufficient to maintain normal coagulation time in adults. DRIs were therefore set at 5-10 $\mu \mathrm{g}$ for children aged <1 year, 15-58 $\mu \mathrm{g}$ for children and adolescents, $55 \mu \mathrm{g}$ for adult women, including those pregnant and lactating, and $65 \mu \mathrm{g}$ for men. No tolerable upper intake level data is available for this vitamin.

\section{Vitamin C}

DRI is $25-30 \mathrm{mg}$ for children aged $<1$ year and $30-40 \mathrm{mg}$ for older children and adolescents. In order to enhance this nutrient's antioxidant action, $75 \mathrm{mg}$ is recommended for women, $90 \mathrm{mg}$ for men, $100 \mathrm{mg}$ for pregnant women, and $120 \mathrm{mg}$ for lactating women. An additional $35 \mathrm{mg}$ is recommended for smokers, given the high oxidative stress associated with smoking. Tolerable upper intake levels are $400 \mathrm{mg}$ for children aged $<3$ years, $650 \mathrm{mg}$ for children aged $\leq 8$ years, $1200-1800 \mathrm{mg}$ for children aged 9-18 years, and $2000 \mathrm{mg}$ for adults.

\section{Vitamin B Complex and Choline}

The DRI for each B-complex component was established based on its general organic functions and on deficiency prevention.

- Folic acid The term "Dietary Folate Equivalent" (DFE) was adopted in response to the variable absorption of different folic acid compounds: 1 DFE $=1.0 \mu \mathrm{g}$ folate content in food or $0.6 \mu \mathrm{g}$ added to or taken with food, or 0.5 $\mu \mathrm{g}$ as a medical supplement taken on an empty stomach. Folic acid recommendations are 65-200 DFE for children aged $\leq 6$ years, 300 DFE for children aged $7-13$ years, 400 DFE for everyone aged $\geq 14$ years, 500 DFE for lactating women, and 600 DFE for pregnant women as prevention against neural tube defects in newborns. The tolerable upper intake level was established as 800-1000 DFE. As it is difficult for pregnant and lactating women to obtain the high folic acid DRI levels from natural food, fortified foods or safe pharmacological supplements are recommended.

- Vitamin B1 (Thiamine) The recommendation for this nutrient is closely related to energy and carbohydrate metabolism. Adequate nutritional status is provided by $0.5 \mathrm{mg} / 1000$ kcal; for pregnant and lactating women, $0.6 \mathrm{mg} / 1000 \mathrm{kcal}$ is recommended. For a wider safety margin, given the high sugar consumption in the Cuban population, the higher intakes proposed in 1996, based on higher recommended energy intakes, were maintained. Minimum recommended intake for adults is $1 \mathrm{mg}$ if less than $1000 \mathrm{kcal}$ are consumed. No tolerable upper intake level data is available.

- Vitamin B2 (Riboflavin) Intake requirements of 1-3 mg for this nutrient have not been modified greatly in recent years. Like thiamine, riboflavin is closely related to energy metabolism. A $0.6 \mathrm{mg} / 1000 \mathrm{kcal}$ recommendation is acceptable; pregnant and lactating women should add $0.3 \mathrm{mg}$ and 0.5 $\mathrm{mg}$, respectively. As with thiamine, and for the same reason, the 1996 recommendations are maintained. Minimum recommended intake for adults is $1.2 \mathrm{mg}$. No tolerable upper intake level data is available.

- Niacin Protein metabolism and niacin are closely related. A share of this nutrient's requirement is fulfilled by tryptophan in 
the diet: $60 \mathrm{mg}$ tryptophan supplies an average of $1 \mathrm{mg}$ niacin. The niacin equivalent (NE) is based on this ratio: $1 \mathrm{NE}=$ $1 \mathrm{mg}$ niacin $=60 \mathrm{mg}$ dietary tryptophan. Niacin recommendations are based on caloric contribution. For children aged $<6$ months, $8 \mathrm{mg} / 100 \mathrm{kcal}$ is recommended; for all other ages, 7 $\mathrm{mg} / 1000 \mathrm{kcal}$. An additional $2 \mathrm{mg}$ and $5 \mathrm{mg}$, are recommended during pregnancy and lactation, respectively. Tolerable upper intake values are 10-15 mg for children aged 1-8 years, $20 \mathrm{mg}$ for children aged 9-13 years, and $30-35 \mathrm{mg}$ for adults.

- Vitamin B6 (Piridoxine. Based on the relationship between this nutrient and protein, DRI is $0.02 \mathrm{mg} / \mathrm{g}$ protein. Tolerable upper intake levels are $30 \mathrm{mg}$ for children aged $1-3$ years and $100 \mathrm{mg}$ for adults.

- Vitamin B12 (Ciancobalamine) DRI is 1.1-2.4 $\mu \mathrm{g}$ for children and adults. Until more reliable data is available on requirements for older adults, pharmacological supplements or fortified foods are recommended. Vitamin B12 is only found in animal products, so strictly vegetarian diets can be lacking in this nutrient. In such cases, fortified foods or supplements are recommended. No tolerable upper intake level data is available.

- Pantothenic acid No intake requirement has been established; DRI is based on observed intake sufficient to replace urinary excretion levels in healthy populations. Adequate intake $1.7-5.0 \mathrm{mg}$, depending on age, $6.0 \mathrm{mg}$ for pregnant women, and $7.0 \mathrm{mg}$ for lactating women. No tolerable upper intake level data is available.

- Biotine Adequate intake, based on observed intake in limited groups, ranges from $5 \mu \mathrm{g}$ for infants to $30 \mu \mathrm{g}$ for adults and pregnant women, and $35 \mu \mathrm{g}$ for lactating women. No tolerable upper intake level data is available.

- Choline Adequate intake is based primarily on levels necessary to maintain liver function and prevent memory disorders. Recommended adequate intake, first established in 2002 by the Food and Nutrition Board of the US National Academy of Sciences, are 125-150 mg/day for children aged $<1$ year, 200-250 mg/day for children aged $1-8$ years, $375 \mathrm{mg} /$ day for those aged 9-13 years, 400-550 mg/day for children aged $\geq 13$ years and adults, $450 \mathrm{mg} /$ day for pregnant women, and $550 \mathrm{mg} /$ day for lactating women. Tolerable upper intake levels of 1-3.5 grams have been proposed.[4]

\section{Minerals and Trace Elements}

DRIs were based on the 1996 Energy and Nutrient Recommendations for the Cuban Population;[1] on criteria established by the 2001 Joint FAO/WHO Expert Committee,[24] the Food and Nutrition Board of the US National Academy of Sciences, and other countries; and on results of recent INHA studies of the Cuban population's nutritional status for minerals and trace elements.[39-45] For sodium, chlorine and potassium, minimum requirements are proposed, since available elements are insufficient to establish recommended or adequate intake levels.

- Sodium The minimum sodium requirement ranges from 120 $\mathrm{mg}$ in the first months of life to $500 \mathrm{mg}$ in adulthood and during pregnancy and lactation, and may be higher when there is profuse sweating or with certain illnesses. More than $2.3 \mathrm{~g} /$ day sodium ( $5.8 \mathrm{~g}$ kitchen salt) is not recommended. Tolerable upper intake levels are 1.5-1.9 g for children aged 1-8 years and $2.3 \mathrm{~g}$ for all other ages.

- Chlorine Minimum requirements range from $180 \mathrm{mg}$ in the first months of life to $750 \mathrm{mg}$ for pregnant and lactating women. A $5 \mathrm{~g} /$ day intake of common salt provides 2100 $\mathrm{mg}$ of chlorine, almost three times the highest minimum requirement.

- Potassium Minimum requirements range from $500 \mathrm{mg}$ for infants to $2000 \mathrm{mg}$ for adults. Adult tolerable upper intake level is $3500 \mathrm{mg} /$ day.

- Calcium Calcium deficiency, as well as the inefficient utilization of calcium by metabolism, is a current topic in nutrition research. Many dietary, hormonal and lifestyle factors influence the bioavailability of this nutrient; therefore, increasing recommended intake levels does not make sense without considering these other factors. Adequate intakes (Als) have been proposed that can be attained practically: $300-600 \mathrm{mg}$ for children aged $<7$ years; $800 \mathrm{mg}$ for children aged $\geq 7$ years and adults; and $1000 \mathrm{mg}$ for pregnant and lactating women. Tolerable upper intake levels are $2500 \mathrm{mg} /$ day for children aged $>1$ year and adults.

- Phosphorus DRIs are determined by calcium Als and were therefore set at 200-275 mg for children aged <1 year, 500$600 \mathrm{mg}$ for children aged 1-7 years, $800 \mathrm{mg}$ for children aged $\geq 7$ years and adults, and $1000 \mathrm{mg}$ for pregnant and lactating women. The calcium to phosphorus ratio is 1.5 for children aged $<1$ year and 1.0 for all other ages. Tolerable upper intake levels are $3000 \mathrm{mg}$ for children aged 1-8 years and adults aged $\geq 70$ years; $4000 \mathrm{mg}$ for children and adults aged 9-69; $3500 \mathrm{mg}$ for pregnant women and $4000 \mathrm{mg}$ for lactating women.

- Magnesium Given this mineral's importance, the DRIs established in 1996 are considered adequate and were maintained, ranging from $50-150 \mathrm{mg}$ for children aged $<2$ years to $500 \mathrm{mg}$ during pregnancy and lactation. Tolerable upper intake level is $65-110 \mathrm{mg}$ for children and $350 \mathrm{mg}$ for adults (only as chemically-synthesized supplements and not from food).

- Iron The most recent research on iron metabolism and Cuba's nutritional status for iron were taken into account. DRI calculations assumed that Cubans consume a mixed diet with intermediate iron bioavailability. Recommended amounts were raised for children aged 6 months to 12 years, adults aged $\geq 18$ years, and lactating women. Iron bioavailability is affected by many factors that should be considered when creating diets. For example, simultaneous intake of $25-100 \mathrm{mg}$ of vitamin C can increase non-heminic iron absorption 2-4 times. Given the high recommended iron intake for pregnant women $(30 \mathrm{mg})$, foods fortified with this nutrient or pharmacological supplements are recommended. Tolerable upper intake levels are $40 \mathrm{mg}$ for children and adolescents, and $45 \mathrm{mg}$ for adults.

- Selenium The 1996 DRI was maintained without including the 2001 Joint FAO/WHO Expert Committee proposal to reduce it by $50 \%$. These much higher recommendations should help protect against frequent complications of the chronic diseases most prevalent in Cuba. The safety margin provided by the $400 \mu \mathrm{g}$ adult tolerable upper intake level is adequate to sustain these recommendations. Tolerable upper intake levels are $45-90 \mu \mathrm{g}$ for children aged $\geq 3$ years, 150-280 $\mu \mathrm{g}$ for children aged $4-13$ years, and $400 \mu \mathrm{g}$ for all other ages.

- Manganese Since existing data is insufficient to establish DRIs, adequate intake amounts were proposed. Tolerable upper intake levels are $2-6 \mathrm{mg}$ for children and $11 \mathrm{mg}$ for adults. 
- Zinc In order to provide a wider safety margin, low bioavailabilty of this nutrient in the diet was assumed. Adult tolerable upper intake level is $40 \mathrm{mg} /$ day.

- Copper DRIs for this nutrient were set for the first time at $400-700 \mu \mathrm{g}$ for children $<1$ year and $900 \mu \mathrm{g}$ for all other ages, including pregnant and lactating women. Tolerable upper intake levels are 1000-5000 $\mu \mathrm{g}$ for children aged 1-13 years and 10,000 $\mu \mathrm{g}$ for adults.

- lodine The DRI for children aged <6 months was raised considerably, compared to the 1996 recommendation, but is similar for all other groups, reaching 200 $\mu \mathrm{g}$ for pregnant and lactating women. Tolerable upper intake level is $200-600 \mu \mathrm{g}$ for children aged $1-13$ years and $1100 \mu \mathrm{g}$ for adults.

- Fluoride Adequate intake is the amount required to reduce risk of dental cavities without producing side effects. Tolerable upper intake level for adults is $10 \mathrm{mg}$.

- Molybdenum DRI is $45 \mathrm{mg}$ for men and women, and $50 \mathrm{mg}$ for pregnant and lactating women. This value is significantly lower than the 75-250 $\mu \mathrm{g}$ previously proposed by the Food and Nutrition Board of the US National Academy of Sciences. Tolerable upper intake levels are 100-600 $\mu \mathrm{g}$ for children aged 1-8 years, $1100 \mu \mathrm{g}$ for children aged 9-13 years and 1700-2000 $\mu \mathrm{g}$ for adults.

- Chromium Adequate intake values are 35 $\mu \mathrm{g}$ for men, $25 \mu \mathrm{g}$ for women, $30 \mu \mathrm{g}$ during pregnancy and $45 \mu \mathrm{g}$ for lactating women. Although tolerable upper intake levels are not established, caution is recommended to avoid exceeding established limits.

\section{Population-Averaged Dietary Refer- ence Intakes for Cuba (Table 3)}

Population-averaged food energy and macronutrient reference intakes are essential inputs for national food planning and availability assessment. Averaged dietary reference intakes from 2001 were updated based on the new DRIs for energy and nutrients presented in this document and calculated using the 1990 FAO methodology,[46] the 2006 Cuban population structure according to the National Statistics Bureau (ONE, its Spanish acronym), and population groupings used by the Cuban Ministry of Domestic Trade for food distribution.

Table 3: Population-Averaged Dietary Reference Intakes, Cuba

\begin{tabular}{|l|r|r|r|r|r|r|r|}
\hline & Total & \multicolumn{7}{|c|}{ Age Groups (years) } \\
\cline { 3 - 9 } & Population & $\mathbf{0 - 2}$ & $\mathbf{3 - 6}$ & $\mathbf{7 - 1 3}$ & $\mathbf{1 4 - 1 7}$ & $\mathbf{1 8 - 6 0}$ & $>$ 70 \\
\hline Energy (kcal) & 2300 & 1074 & 1638 & 2101 & 2611 & 2457 & 2079 \\
\hline Protein (g) & 69 & 31 & 49 & 63 & 78 & 74 & 62 \\
\hline Fat (g) & 53 & 42 & 46 & 54 & 58 & 55 & 46 \\
\hline Essential Fatty Acids (g) & 20 & 11 & 15 & 19 & 23 & 22 & 19 \\
\hline Total Carbohydrates (g) & 385 & 142 & 258 & 341 & 444 & 418 & 354 \\
\hline Complex Carbohydrates (g) & 288 & 107 & 192 & 257 & 333 & 313 & 265 \\
\hline Simple Carbohydrates (g) & 97 & 35 & 66 & 84 & 111 & 105 & 88 \\
\hline
\end{tabular}

\section{Vitamins}

\begin{tabular}{l|l}
\hline Vitamin A $(\mu \mathrm{g})$ \\
Vitamin D $(\mu \mathrm{g})$
\end{tabular}

\begin{tabular}{|l|r|r|r|r|r|r|r|}
\hline Vitamin $\mathrm{E}(\mathrm{mg})$ & 14 & 6 & 7 & 9 & 15 & 15 & 15 \\
\hline Vitamin $\mathrm{K}(\mu \mathrm{g})$ & 54 & 13 & 20 & 37 & 47 & 60 & 60 \\
\hline Vitamin $\mathrm{C}(\mathrm{mg})$ & 72 & 30 & 30 & 38 & 40 & 82 & 83 \\
\hline Vitamin $\mathrm{B}_{1}(\mathrm{mg})$ & 1.2 & 0.6 & 0.8 & 1.0 & 1.2 & 1.4 & 1.2 \\
\hline Vitamin $\mathrm{B}_{2}(\mathrm{mg})$ & 1.5 & 0.7 & 1.0 & 1.2 & 1.5 & 1.6 & 1.4 \\
\hline Niacin $(\mathrm{mg})$ & 17 & 8 & 12 & 15 & 18 & 19 & 17 \\
\hline Vitamin $\mathrm{B}_{6}(\mathrm{mg})$ & 2.0 & 0.8 & 1.3 & 1.7 & 2.0 & 2.1 & 2.1 \\
\hline Vitamin $\mathrm{B}_{12}(\mu \mathrm{g})$ & 2.3 & 1.0 & 1.7 & 2.2 & 2.4 & 2.4 & 2.4 \\
\hline Folic acid $(\mu \mathrm{g})$ & 373 & 116 & 200 & 300 & 400 & 400 & 400 \\
\hline Pantothenic acid $(\mathrm{mg})$ & 5 & 2 & 3 & 5 & 5 & 5 & 5 \\
\hline Biotine $(\mu \mathrm{g})$ & 28 & 7 & 12 & 23 & 25 & 30 & 30 \\
\hline
\end{tabular}

\section{Minerals}

\begin{tabular}{|l|r|r|r|r|r|r|r|}
\hline Calcium (mg) & 785 & 378 & 553 & 800 & 800 & 800 & 800 \\
\hline Phosphorous (mg) & 702 & 288 & 447 & 672 & 900 & 700 & 800 \\
\hline Iron $(\mathrm{mg})$ & 16 & 11 & 12 & 14 & 17 & 17 & 13 \\
\hline Zinc $(\mathrm{mg})$ & 12 & 4 & 9 & 14 & 16 & 12 & 12 \\
\hline Copper $(\mu \mathrm{g})$ & 893 & 658 & 853 & 900 & 900 & 900 & 900 \\
\hline Sodium $(\mathrm{mg})$ & 482 & 168 & 354 & 479 & 500 & 500 & 500 \\
\hline Potassium (mg) & 1930 & 700 & 1400 & 1900 & 2000 & 2000 & 2000 \\
\hline Magnesium (mg) & 309 & 82 & 169 & 293 & 351 & 325 & 324 \\
\hline Manganese (mg) & 2 & 1 & 1 & 2 & 2 & 2 & 2 \\
\hline lodine $(\mu \mathrm{mg})$ & 146 & 90 & 115 & 137 & 150 & 150 & 150 \\
\hline Chromium $(\mu \mathrm{m})$ & 27 & 4 & 12 & 22 & 30 & 30 & 25 \\
\hline Selenium $(\mu \mathrm{g})$ & 50 & 14 & 19 & 31 & 50 & 55 & 55 \\
\hline Fluoride (mg) & 2 & 0 & 1 & 3 & 3 & 3 & 5 \\
\hline Energy Contribution (\%) & & & & & & & \\
\hline Protein & 12 & 12 & 12 & 12 & 12 & 12 & 12 \\
\hline Total fat & 21 & 35 & 25 & 23 & 20 & 20 & 20 \\
\hline Essential fatty acids & 8 & 9 & 8 & 8 & 8 & 8 & 8 \\
\hline Total carbohydrates & 67 & 53 & 63 & 65 & 68 & 68 & 68 \\
\hline Complex carbohydrates & 50 & 40 & 47 & 49 & 51 & 51 & 51 \\
\hline Simple carbohydrates & 17 & 13 & 16 & 16 & 17 & 17 & 17 \\
\hline
\end{tabular}

Reference intakes for food energy corresponding to an "active" PAL were used for adult men, while intakes corresponding to a "low active" PAL was used for women. Height values of $1.72 \mathrm{~m}$ for men and $1.60 \mathrm{~m}$ for women, representing the 75 th percentile in anthropometric charts of the Cuban population, were used. [47] Additional requirements of pregnant and lactating women were estimated based on 115,000 pregnant women per year (considering the number of live births), a figure obtained from the Cuban Ministry of Health's 2007 Statistical Yearbook.[48]

The following percentages of macronutrient contributions to total energy intake from food were used:

Protein: $10 \%$ energy, children aged $<1$ year, $12 \%$ all other ages. Fat: $40 \%$ energy for infants aged $<6$ months, $35 \%$ for children 
aged 6 months to 2 years, 25\% for children aged $2-6$ years, $23 \%$ for children aged $7-13$ years, and $20 \%$ for all other ages.

Essential amino acids: $8 \%$ total energy.

Carbohydrates: Calculated as the percentage remaining once protein and fat portions of total energy intake has been established. Complex carbohydrates should make up $75 \%$ of the recommended carbohydrate intake.

For dietary planning purposes, adding $20 \%$ to the $2300 \mathrm{kcal} /$ day averaged reference intake for the Cuban population is recommended.

Nutritional Supplements and Fortified Foods At present, no study has demonstrated that taking isolated chemicallysynthesized nutrients has the same beneficial effect as that associated with eating fruits, vegetables, whole grains, legumes and other natural food. These effects may be due to the combined, synergistic action of multiple components in food, many of which are as yet unidentified. This point of view is timely in an age when supplements and fortified foods in relatively concentrated form are heavily abused for the purpose of satisfying dietary reference intake amounts. Ideally, nutritional needs can be satisfied with food, although consideration can be made for some nutrients and vulnerable groups, such as iron and folic acid for pregnant women, whose high demands are not easily met with current diets.

\section{ACKNOWLEDGMENTS}

The following collaborators made valuable contributions to Dietary Reference Intakes for the Cuban Population, 2008.

Vladimir Ruiz, MD, MS, Magaly Padrón, Gisela Pita, MD, MS, Consuelo Macías, PhD, Yeneisy Lanyau, MS, Daisy Zulueta, MD, MS, Maria Elena Díaz, MS, PhD, Mayttel de la Paz Luna, MS, Beatriz Basabe, MS, PhD, Blanca Terry, MD, MS, Alejandrina Cabrera, PhD, Moisés Hernández, MD, MS, Elisa Aznar PhD, Lázaro Alfonso, MD, MS, Rita Castiñeiras, PhD, Jorge René Fernández, MD, MS, Norma Silva, MD, MS, Berta Rodríguez, MD. - $/$ L

\section{References \& Notes}

1. Porrata $C$, Hernández-Triana $M$, Argüelles JM Recomendaciones nutricionales y guías de alimentación para la población cubana. Havana: Editorial Pueblo y Educación; 1996.

2. Hernández-Triana M. Recomendaciones nutricionales para el ser humano. Actualización. Rev Cubana Invest Biomed. 2004;23(4):266-92.

3. FAO/WHO/UNU Expert Consultation. Report on Human Energy Requirements. Pub Health Nutr. 2005;8(1):929-1228.

4. Panel on Macronutrients, Subcommittees on Upper Reference Levels of Nutrients and Interpretation and Uses of Dietary Reference Intakes, and the Standing Committee on the Scientific Evaluation of Dietary Reference Intakes, Food and Nutrition Board, Institute of Medicine of the National Academies. Dietary Reference Intakes for Energy, Carbohydrate, Fiber, Fat, Fatty Acids, Cholesterol, Protein, and Amino Acids. Washington, DC: National Academies Press, 2005.

5. This article is adapted from Recomendaciones nutricionales para la población cubana (versión resumida), available from http://www.inha.sld. cu/Documentos/RN Ver Resum 20 Feb 2009. pdf. See also Recomendaciones nutricionales para la población cubana, 2008 Estudio mulicéntrico. Revista Cubana de Investigaciones Biomédicas, 2009, Vol. 28, No. 2, available from http://bvs.sld.cu/revistas/ibi/ibm209/ ibm010209..pdf.

6. The following institutions were involved in producing the 2008 edition of the Dietary Reference Intakes for the Cuban Population: Nutrition and Food Hygiene Institute (INHA), Finlay Institute, University of Havana Biology Department, Food Research Institute, Julio Trigo López Medical School, National Bioproducts Center, William Soler Pediatric Teaching Hospital, National Economic Research Institute, 10 de Octobre Maternal-Child Teaching Hospital, National Obstetrics and Gynecology Group, National Endocrinology Institute.

7. WHO Multicentre Growth Reference Study Group. WHO Child Growth Standards: length/ height-for-age, weight-for-age, weight-for-length, weight-for-height and body mass index-for-age: methods and development [monograph on the Internet]. Geneva: WHO; 2006 [cited 2008 Sep 22]. Available from: http://www. who.int/ childgrowth/en.
8. Esquivel M, Berdasco A, González C, Gutiérrez JA. Cambios ocurridos en el desarrollo físico y el estado nutricional de niños y adolescentes de la ciudad de La Habana entre 1972 y 2005. Final Report. Havana: Human Growth and Development Department, Higher Institute of Medical Sciences, Havana; 2006

9. Hernández-Triana $M$, Salazar G, Díaz E, González S, Sánchez V, Basabe B, et al. Total energy expenditure by the doubly-labelled water method in rural preschool children in Cuba. Stable Isotope Workshop. Annals Nutr Metab. 2001;45(Suppl I):352.

10. Hernández-Triana M, Salazar G, Díaz E, Sánchez V, Basabe B, González S. Total energy expenditure by the doubly-labelled water method in rural preschool children in Cuba. Food Nutr Bull. 2002;23(Suppl 3):76-81.

11. WHO Energy and protein requirements: Report of a Joint FAO/WHO/UNU Expert Consultation. WHO Technical Report Series No. 724. Geneva: WHO; 1985.

12. Hernández-Triana $M$, Porrata $C$ Energy Requirements and Physical Activity Levels of Elderly People in Cuba. Food Nutr Bull. 2002;23(3 Suppl):S82-6.

13. Hernández-Triana M, Salazar G, Sánchez V, Basabe $B$, Valencia $M$. Total energy expenditure in elderly subjects from a rural mountain community in Cuba, by questionnaire and resting metabolic rate (factorial method), compared with the doubly-labelled water method as gold standard. Annals Nutr Metab. 2001;45(Suppl I):354

14. Hernández-Triana M, Bayley $\mathrm{H}$, Porrata $\mathrm{C}$, Monterrey P, Estrada G, Diaz ME, et al. Total Energy Expenditure measured with the doubly-labelled water technique in women from 60-70 years of age from Havana City, Cuba. Annals Nutr Metab. 2001;45(Suppl I):351.

15. Alemán-Mateo $\mathrm{H}$, Salazar $\mathrm{G}$, Hernández-Triana M, Valencia-Julleirat M. Total Energy expenditure, resting metabolic rate and physical activity level in free-living rural elderly men and women from Cuba, Chile and México. Eur J Clin Nutr. 2006;60:1258-65.

16. Valencia-Julleirat ME, Alemán-Mateo $\mathrm{H}$, Salazar G, Hernández-Triana M. Body composition by hydrometry (deuterium oxide dilution) and bioelectrical impedance in subjects aged 60y from rural regions of Cuba, Chile and Mexico. Int J Obes. 2003;27:848-55.

17. Hernández-Triana M. Requerimientos de energía alimentaria para la población adulta. Rev Cubana Hig Epidemiol [serial on the Internet]. 2005 Sep 13 [cited 2008 Sep 13];43(1). Available from: http:// www.bvs.sld.cu/revistas/hie/indice.html

18. Jiménez S, Díaz ME, Barroso I, Bonet M, Cabrera A, Wong I. Estado nutricional de la población cubana adulta. Rev Española Nutr Comunitaria. 2005;11(1):18-26.

19. Joint WHO/FAO Expert Consultation on Diet, Nutrition and the Prevention of Chronic Diseases, Draft. Geneva: WHO; 2002 March 28.

20. Díaz-Sánchez ME, Montero M, Jiménez-Acosta S. Valores de referencia nacionales para aumento de peso durante el embarazo. Informe Final de Tema de Investigación 2005-2007. Havana: Nutrition and Food Hygiene Institute; 2008.

21. Protein and Amino Acid Requirements in Human Nutrition. Report of the Joint FAO/WHO/UNU Expert Consultation on Protein and Amino Acid Requirements in Human Nutrition (2002: Geneva, Switzerland). WHO Technical Report Series 935. Geneva: WHO; 2007.

22. Pan American Health Organization. Aceites saludables y la eliminación de ácidos grasos trans de origen industrial en las Américas: iniciativa para la prevención de enfermedades crónicas [monograph on the Internet]. Washington, D.C.: OPS; 2008 [cited 2008 Oct 18]. Available from: http://www.msal.gov.ar/argentina_saludable/pdf/ aceites-saludables.pdf

23. Williams CL. Importance of dietary fiber in childhood. J Am Diet Assoc. 1995;95(10):1140-6.

24. Vitamin and Mineral Requirements in Human Nutrition. Report of a joint FAO/WHO expert consultation Bangkok, Thailand. 2nd edition. Rome: FAO/WHO; 2004.

25. Lanyau Y, Macías C, Serrano G, Herrera D, Reyes $D$, Ferret $A$, et al. Niveles e ingestión dietética de la vitamina B1 en un grupo de adultos sanos de la ciudad de La Habana. Rev Española Nutr Comunitaria. 2007;13(34):153-7.

26. Lanyau $\mathrm{Y}$, Hernández-Triana M, Martín I, Díaz ME, Toledo E, Reyes D, et al. Estado nutricional de la vitamina B1 en adultos mayores no institu- 
cionalizados. Rev Española de Nutrición Comunitaria. 2005;11(1):34-40

27. Lanyau $\mathrm{Y}$, Hernández-Triana $\mathrm{M}$, Macias-Matos C, Zhou D. Is B vitamins deficiency associated with prevalence of Alzheimer Disease in Cuban Elderly. Nutr Health. 2006;18:103-18.

28. Lanyau Y, Pineda D, Hernández-Triana M, Martín I, Díaz ME, Toledo E. Estado nutricional y vitaminas B1 y B2 en ancianos no institucionalizados. Rev Cubana Salud Pub. 2003:29(3):209-14.

29. Pita G, Hernández-Triana M, Cabrera A, Martín I, Macías C. Evaluación nutricional de la vitamina $\mathrm{E}$ de un grupo de adultos mayores de Ciudad de la Habana. Rev Española Nutr Comunitaria. 2004;10(3):114-20

30. Macías C, Pita G, Monterrey P, Reboso J. Vitamin A status in Cuban children aged 6-11 years. Pub Health Nutr. 2008;11(1):95-101.

31. Macías C, Schweigert FJ, Pita G, Hurtienne A, Serrano G, Quintero ME, et al. Carotenoides y retinol plasmáticos en embarazadas a término y mujeres no embarazadas. Rev Española Nutr Comunitaria. 2006;12(1):30-7.

32. Macías C, Pita G, Monterrey P, Alonso E, Ramos MA. Estado nutricional de la vitamina $A$ en niños cubanos de 6 a 24 meses de edad. Rev Cubana Aliment Nutr. 2002;16:95-104.

33. Macías C, Schweigert F, Serrano G, Pita G, Hurtienne A, Reyes D, et al. Carotenoides séricos y su relación con la dieta en un grupo de adultos cubanos. Rev Cubana Aliment Nutr. 2002;16:105-13.

34. Pita G, Pineda D, Serrano G, Macías C, Cabrera A, Rodríguez $Y$, et al. Vitaminas antioxidantes en un grupo de embarazadas y recién nacidos durante un año de estudio. Rev Cubana Aliment Nutr. 2002;16:85-94.
35. Macías C, Schweigert FJ. Changes in the concentration of carotenoids, vitamin A, alpha-tocopherol and total lipids in human milk throughout early lactation. Ann Nutr Metab. 2001;45:82-5.

36. Lanyau $\mathrm{Y}$, Macías $\mathrm{C}$, Jiménez $\mathrm{S}$. Estado nutricional de vitaminas del complejo $B$ en 2 grupos de trabajadores industriales de Ciudad de la Habana. Rev Cubana Aliment Nutr. 2000;14(1):7-13.

37. Pita G, Serrano G, Cabrera A, Macías C, Hernández MA. Vitaminas antioxidantes en un grupo de adolescentes como factor de riesgo de enfermedades cardiovasculares. Rev. Cubana Aliment Nutr. 2000;14(1):79-85.

38. Hernández-Triana M, Porrata-Maury $C$, JiménezAcosta S. Toxicidad de la vitamina A en el embarazo. RESUMED. 1998;11(3):153-60.

39. Reboso J, Jiménez S, Monterrey P, Macías C, Pita G, Selva L, et al. Diagnóstico de la anemia por deficiencia de hierro en niños de 6 a 24 meses y de 6 a 12 años de edad de las provincias orientales de Cuba. Rev Española Nutr Comunitaria. 2005;11(2):60-9.

40. Reboso J, Pita G, Macías C, Jiménez S. Frecuencia de consumo de alimentos y anemia en escolares de primaria de las regiones occidental y central de Cuba. Rev Española Nutr Comunitaria. 2006;12(1):22-9.

41. Lopéz A, Reboso J, Portuondo R, Díaz ME. Efecto del uso de Trofin sobre el estado de nutrición de hierro en niños desnutridos menores de dos años con anemia ferripriva. Rev Española Nutr Comunitaria. 2004;10(2):56-63.

42. Ruiz-Álvarez V, Reboso-Pérez J, Hernández-Triana M. Asociación entre la infección por Helicobacter pylori y anemia en niños de edad escolar. Rev Cubana Invest Biomed [serial on the Inter- net]. 2005 [cited 2008 Sep 12];24(2):[about 7 p.]. Available from: http://www.bvs.sld.cu/revistas/ibi/ indice.html

43. Macías C, Basabe B, Pita G. Experiencias de un programa participativo de educación nutricional en adolescentes de 12 a 15 años (Brochure). Havana: Nutrition and Food Hygiene Institute, Ministry of Public Health (CU), UNICEF; 2007

44. Santos I, Boccio J, Davidsson L, HernandezTriana M, Huanca-Sardinas E, Janjetic M, et al. Helicobacter pylori is not associated with anemia in Latin America: Results from Argentina, Brazil, Bolivia, Cuba, México and Venezuela. Public Health Nutr. 2009; 12(10):1862-70.

45. De La Paz M, Basabe B, Zulueta D, Terry B, Granado S, Quintero ME, et al. Excreción urinaria de yodo en el monitoreo del programa para la eliminación de los desórdenes por deficiencia de yodo. Rev Cubana Aliment Nutr. 2008;18(1):72-83.

46. James WPT, Schofield EC. Human Energy Requirements. A Manual for planners and nutritionists. New York: Oxford University Press; 1990. p. 22-7.

47. Berdasco A. Romero JM. Analysis and interpretation of Cuban adult anthropometry based on some classification variables. Nutr Consultants Report Series 88. Rome: FAO, 1992.

48. Anuario Estadístico de Salud 2007 [Internet]. Havana: Ministry of Public Health, National Statistics Division; 2008 [cited 2008 Sep 20]. Available from: http://bvs.sld.cu/cgi-bin/wxis/ anuario/? IsisScript=anuario/iah.xis\&tag5003=an uario \&tag5021=e\&tag6000=B\&tag5013=GUEST \&tag5022=2007 